\title{
P2Y, receptor switches to neurons from glia in juvenile versus neonatal rat cerebellar cortex
}

\author{
Susanna Amadio수, Fabrizio Vacca1 ${ }^{1}$, Alessandro Martorana ${ }^{2}$, \\ Giuseppe Sancesario ${ }^{2}$ and Cinzia Volonté*1,3
}

Address: ${ }^{2}$ Santa Lucia Foundation, Via del Fosso di Fiorano 64, 00143 Roma, Italy, ${ }^{2}$ University of Rome Tor Vergata, Facoltà di Medicina, Dipartimento di Neuroscienze, Roma, Italy and '3nstitute of Neurobiology \& Molecular Medicine, CNR, Via del Fosso di Fiorano 64, 00143 Roma, Italy

Email: Susanna Amadio - s.amadio@hsantalucia.it; Fabrizio Vacca - f.vacca@hsantalucia.it; Alessandro Martorana - mrtlsn02@uniroma2.it; Giuseppe Sancesario - sancesario@med.uniroma2.it; Cinzia Volonté* - cinzia.volonte@inmm.cnr.it

* Corresponding author

Published: 28 June 2007

BMC Developmental Biology 2007, 7:77 doi:10.1186/147|-2/3X-7-77
Received: 12 April 2007

Accepted: 28 June 2007

This article is available from: http://www.biomedcentral.com/I47I-2/3X/7/77

(c) 2007 Amadio et al; licensee BioMed Central Ltd.

This is an Open Access article distributed under the terms of the Creative Commons Attribution License (http://creativecommons.org/licenses/by/2.0), which permits unrestricted use, distribution, and reproduction in any medium, provided the original work is properly cited.

\begin{abstract}
Background: In the CNS, several P2 receptors for extracellular nucleotides are identified on neurons and glial cells to participate to neuron-neuron, glia-glia and glia-neuron communication.

Results: In this work, we describe the cellular and subcellular presence of metabotropic P2Y, receptor in rat cerebellum at two distinct developmental ages, by means of immunofluorescenceconfocal and electron microscopy as well as western blotting and direct membrane separation techniques. At postnatal day 2I, we find that P2Y, receptor in addition to Purkinje neurons, is abundant on neuronal specializations identified as noradrenergic by anatomical, morphological and biochemical features. P2Y, receptor immunoreactivity colocalizes with dopamine $\beta$-hydroxylase, tyrosine hydroxylase, neurofilament light chain, synaptophysin and flotillin, but not with glial fibrillary acidic protein for astrocytes. $P 2 Y$, receptor is found enriched in membrane microdomains such as lipid rafts, in cerebellar synaptic vesicles, and is moreover visualized on synaptic varicosities by electron microscopy analysis. When examined at postnatal day 7, P2Y, receptor immunoreactivity is instead predominantly expressed only on Bergmann and astroglial cells, as shown by colocalization with glial fibrillary acidic protein rather then neuronal markers. At this age, we moreover identify that $\mathrm{P} 2 \mathrm{Y}$, receptor-positive Bergmann fibers wrap up doublecortin-positive granule cells stretching along them, while migrating through the cerebellar layers.

Conclusion: Membrane components including purinergic receptors are already known to mediate cellular contact and aggregation in platelets. Our results suggesting a potential role for $\mathrm{P} 2 \mathrm{Y}$, protein in cell junction/communication and development, are totally innovative for the CNS.
\end{abstract}

\section{Background}

Extracellular nucleotides partake to excitatory neurotransmission and neuromodulation in the CNS and are capable of intervening in a broad array of physiopathological functions acting on different $\mathrm{P} 2$ purinergic receptors [1-3].
Because of their heterogeneous faculty of responding to several diverse nucleotides, interest is growing on discovering the exact localization of the various $\mathrm{P} 2$ receptor subunits in selected organs, tissues and cellular phenotypes $[4,5]$. To date, seven different ionotropic P2X $\left(\mathrm{P} 2 \mathrm{X}_{1-7}\right)[6]$ 
and eight distinct metabotropic P2Y (P2Y $\left.\mathrm{Y}_{1,2,4,6,11,12,13,14}\right)$ [7] receptors were cloned from mammalian species. In contrast to P2X ion channels, P2Y proteins hold the general feature of $G$ protein-coupled receptors with seven hydrophobic transmembrane domains. Since activation of P2Y subtypes leads to second messenger cascades, their response is slower than that mediated by $\mathrm{P} 2 \mathrm{X}$ subunits [810]. Among P2Y receptors, an elevated expression particularly of the $\mathrm{P}_{2} \mathrm{Y}_{1}$ subtype was detected in both human [11] and rat brain [12]. In human tissue, expression of $\mathrm{P}_{2} \mathrm{Y}_{1}$ protein is reported exclusively on neuronal cells in cerebral and cerebellar cortex, in hippocampus, caudateputamen nuclei, globus pallidus, subthalamic nucleus and midbrain [11]. Moreover, $\mathrm{P}_{2} \mathrm{Y}_{1}$ protein appears associated to neurofibrillary tangles and neuritic plaques in postmortem brain of Alzheimer's disease patients [13]. On the contrary, $\mathrm{P}_{2} \mathrm{Y}_{1}$ receptor in rat is detected not only on grey matter, particularly cerebellar, cortical and hippocampal neurons, but also on white matter of corpus callosum and optic nerve [12].

Many studies have already highlighted a general role for purinergic signaling in brain development [14] and in neuron and/or glia function and communication [15-17]. For instance, activation particularly of $\mathrm{P} 2 \mathrm{Y}_{1}$ receptor is suggested to regulate oligodendrocyte progenitor functions [18], whereas reduced levels of $\mathrm{P} 2 \mathrm{Y}_{1}$ protein apparently affect proliferation and migration, but not differentiation of neural progenitor cells during early CNS development [19]. With the present work, we further study $\mathrm{P}_{2} \mathrm{Y}_{1}$ receptor and compare protein distribution in juvenile versus neonatal rat cerebellum. We show that during postnatal growth, the phenotypic appearance of $\mathrm{P}_{2} \mathrm{Y}_{1}$ protein undergoes a drastic switch from glial to neuronal localization, therefore suggesting this receptor as a novel marker of cerebellar development.

\section{Results}

$P 2 Y$, receptor is present on tyrosine hydroxylase- and dopamine $\beta$-hydroxylase-positive neurons in juvenile rat cerebellum

We describe in this work the topographic cellular and subcellular in vivo distribution of $\mathrm{P}_{2} \mathrm{Y}_{1}$ receptor protein in the cerebellum of juvenile rat at postnatal day 21 (P21). We show by confocal microscopy that $\mathrm{P} 2 \mathrm{Y}_{1}$ protein immunoreactivity is uniformly distributed throughout specific zones of cerebellar cortex (Fig. 1). Confirming what was previously depicted by immunohistochemical observations [12], our immunofluorescence studies indicate that $\mathrm{P}_{2} \mathrm{Y}_{1}$ receptor is limited to Purkinje cell (pc) bodies and ramifications, to neuropil of molecular layer $(\mathrm{ml})$, and to axons of white matter irradiating into granule $(\mathrm{gl})$ and Purkinje (pl) layers (Fig. 1, Fig. 2). In addition, we show that specific $\mathrm{P}_{2} \mathrm{Y}_{1}$ receptor staining is absent from NeuNpositive granule cell bodies, but present on the conspicu- ous array of fibers irradiating into the cerebellum and spreading out their projections to granular, Purkinje and molecular layers (Fig. 1). In sagital cerebellar sections, we see by confocal analysis that $\mathrm{P}_{2} \mathrm{Y}_{1}$ receptor immunoreactivity colocalizes with thick, straight and bundled neurofilament light chain (NFL) fluorescence, specific for neuronal processes (Fig. 2A), with tyrosine hydroxylase $(\mathrm{TH})$, the rate-limiting enzyme in catecholamine biosynthesis (Fig. 2B), and with dopamine $\beta$-hydroxylase $(\mathrm{D} \beta \mathrm{H})$, specific for noradrenergic neurons (Fig. 3). We find that, differently from NFL (Fig. 2A), nerve fibers immunoreactive for both $\mathrm{TH}$ (Fig. 2B) or D $3 \mathrm{H}$ (Fig. 3) and $\mathrm{P}_{2} \mathrm{Y}_{1}$ receptor can be much thinner (Fig. 3B, arrows), sparse, unbundled and winding and, moreover, display abundant varicosities and beaded appearance (Fig. 2B, inset c; Fig. 3B, arrow head and inset). Although $\mathrm{P}_{2} \mathrm{Y}_{1}$ receptor labeling is not uniformly distributed along the entire fiber, and not all $\mathrm{D} \beta \mathrm{H}$ ramifications are $\mathrm{P} 2 \mathrm{Y}_{1}$ positive, $\mathrm{P} 2 \mathrm{Y}_{1}$ fibers are densely detected in the white matter of each cerebellar folium without distinction among lobules, sometimes in contact with perikarya (data not shown). At higher magnification and by triple immunofluorescence confocal analysis, we observe that a blue Calbindin-positive Purkinje axon is surrounded by yellow colocalizing signals of red $\mathrm{P}_{2} \mathrm{Y}_{1}$ receptor and green $\mathrm{D} \beta \mathrm{H}$ (Fig. 3C). In this particular fiber, the $\mathrm{P} 2 \mathrm{Y}_{1}$ receptor is absent from the Purkinje axon, but enriched on noradrenergic terminals on the same axon. Moreover, the numerous and large varicosities (1-3 $\mu \mathrm{m}$ diameter) of $\mathrm{TH}-$ positive fibers [20] directly express $\mathrm{P} 2 \mathrm{Y}_{1}$ receptor (Fig. $2 \mathrm{~B}$, inset c) and are, therefore, likely responsible for the beaded appearance of $\mathrm{P} 2 \mathrm{Y}_{1}$ receptor immunostaining. By triple immunofluorescence and confocal analysis on histological sections, we further prove that the $\mathrm{P}_{2} \mathrm{Y}_{1}$ receptorpositive varicosities (red immunofluorescence) are enriched in synaptophysin (specific marker of synaptic structures, green immunofluorescence), and flotillin (a lipid rafts-associated integral membrane protein, blue immunofluorescence) [21], therefore providing a completely overlapping $\mathrm{P}_{2} \mathrm{Y}_{1}$-synaptophysin-flotillin immunoreactive signal (white immunofluorescence, Fig. 4). The large oval/cuboid staining (Fig. 4 insets), as well as the fine punctate staining, further demonstrate the presence of synaptophysin and $\mathrm{P}_{2} \mathrm{Y}_{1}$ receptor labeling on synaptic glomeruli.

On the other hand, P2Y1 receptor does not colocalize with glial fibrillary acidic protein (GFAP), therefore excluding its concurrent expression on astrocytes (Fig. 8B, lower-right inset).

\section{Ultrastructural analysis indicates that $P 2 Y$, receptor is present on both axon terminals and dendrites}

To further investigate the subcellular localization of $\mathrm{P} 2 \mathrm{Y}_{1}$ protein, we performed ultrastructural analysis by electron 

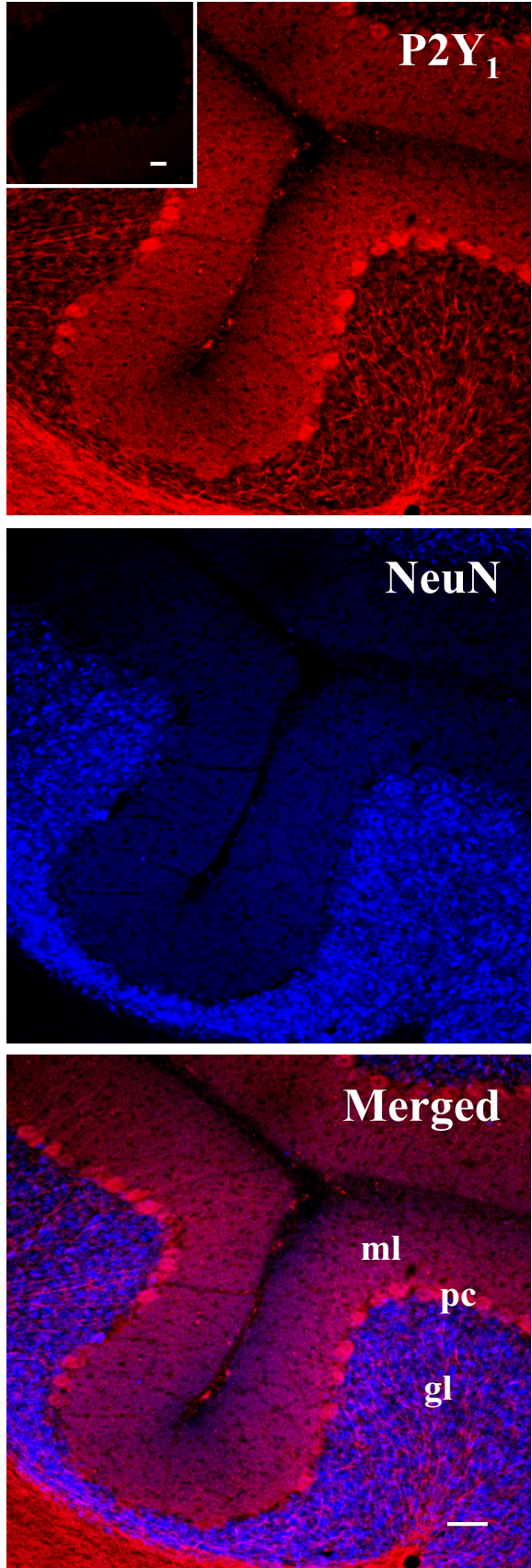

\section{Figure I}

Map of $P 2 Y$, receptor protein in juvenile rat cerebellar cortex. Sagital sections of P2I rat cerebellar cortex were processed for double immunofluorescence analysis. Confocal images show that $\mathrm{P} 2 \mathrm{Y}$, receptor protein (red immunofluorescence) is present on Purkinje cell ( $p c)$ bodies and ramifications, on neuropil of molecular layer $(\mathrm{ml})$, on axons of the white matter irradiating into the granule layer (gl), but not on NeuN-positive granule neurons (blue immunofluorescence). The inset represents immunofluorescence analysis performed in the presence of the immunogenic peptide for $\mathrm{P} 2 \mathrm{Y}_{\mathrm{I}}$ receptor. Scale bars $=50 \mu \mathrm{m}$. microscopy. We confirm the presence of $\mathrm{P}_{2} \mathrm{Y}_{1}$ receptor immunoreactive profiles in all cortical layers of juvenile rat cerebellar cortex, although more abundantly in gl (Fig. $5 \mathrm{~A}$ ), rather than $\mathrm{pl}$ or $\mathrm{ml}$ (Fig. 5B). P2Y $\mathrm{Y}_{1}$ receptor immunoreactivity is moreover present on both dendrites (Fig. 5A, asterisks) and fine, beaded axons (Fig. 5A, white circle, Fig. 5B, arrows) that travel along the cerebellar cortical layers. $\mathrm{P}_{2} \mathrm{Y}_{1}$ immunoreactive axons are un-myelinated and consist of $\mathrm{P}_{2} \mathrm{Y}_{1}$-positive small axonal enlargements or varicosities (Fig. 5C, black arrow) connected by narrower $\mathrm{P}_{2} \mathrm{Y}_{1}$-positive inter-varicose segments (Fig. 5C, white arrow). The varicosities are about $1-2 \mu \mathrm{m}$ in diameter and filled with synaptic pleomorphic vesicles and mitochondria (Fig. 5C and 5D). Intervaricose segments do not contain vesicles. The most remarkable feature of the electron microscopy analysis is the absence of visible synaptic specializations (Fig. 6A-C). The $\mathrm{P}_{2} \mathrm{Y}_{1}$ receptor-positive varicosities are in fact adjacent to cerebellar elements like granule dendrites (Fig. 6A-C) and cell bodies (Fig. 6E), without formation of conventional synaptic junctions (see arrow in Fig. 6C). In addition, specific immunolabelling is observed also in proximal dendrites of Purkinje neurons (Fig. 6F), and very rarely in cell bodies of granule cells (Fig. 6D). No P2Y $\mathrm{Y}_{1}$ receptor-immunolabelled glial cells are observed.

\section{$P 2 Y$, receptor localizes in lipid rafts and synaptosomes}

Since fluorescence microscopy indicated a high degree of co-localization between $\mathrm{P}_{2} \mathrm{Y}_{1}$ receptor and the lipid rafts marker flotillin-2, we purified low buoyant density detergent-resistant membranes (lipid rafts) from P21 rat cerebellum, in order to better dissect the localization of $\mathrm{P}_{2} \mathrm{Y}_{1}$ protein. Whereas in total cerebellar extracts the $\mathrm{P}_{2} \mathrm{Y}_{1}$ receptor is recognized as a major protein band of approximately $120 \mathrm{kDa}$ and a minor band of about $42 \mathrm{kDa}$ (molecular mass expected from aminoacid sequence analysis) (Fig. 7A), the specific form recognized in the absence of the antigenic peptide by the $\mathrm{P}_{2} \mathrm{Y}_{1}$ receptor antiserum in the low density fractions of the sucrose gradient (together with the lipid rafts marker flotillin-2) corresponds not to the monomeric, but to the oligomeric protein (Fig. 7B). This is not surprising, since SDS-resistant oligomeric forms of this receptor are frequently reported, for instance in vascular smooth muscle and endothelial cells, and suggested to be the functional forms [22]. Consistently, when the receptor antiserum used to identify $\mathrm{P} 2 \mathrm{Y}_{1}$ protein is pre-incubated with the immunizing peptide, the reactivity not only to the monomeric, but also to the oligomeric band is completely abolished (Fig. 7A,B), therefore confirming the specificity of the antigen-antiserum interactions. This is further proved by the result that the $\mathrm{P}_{2} \mathrm{Y}_{1}$ receptor polyclonal antiserum used in this study is able to efficiently immunoprecipitate the recombinant Myc-P2 $\mathrm{Y}_{1}$ human receptor transiently transfected in SH-SY5Y cells 

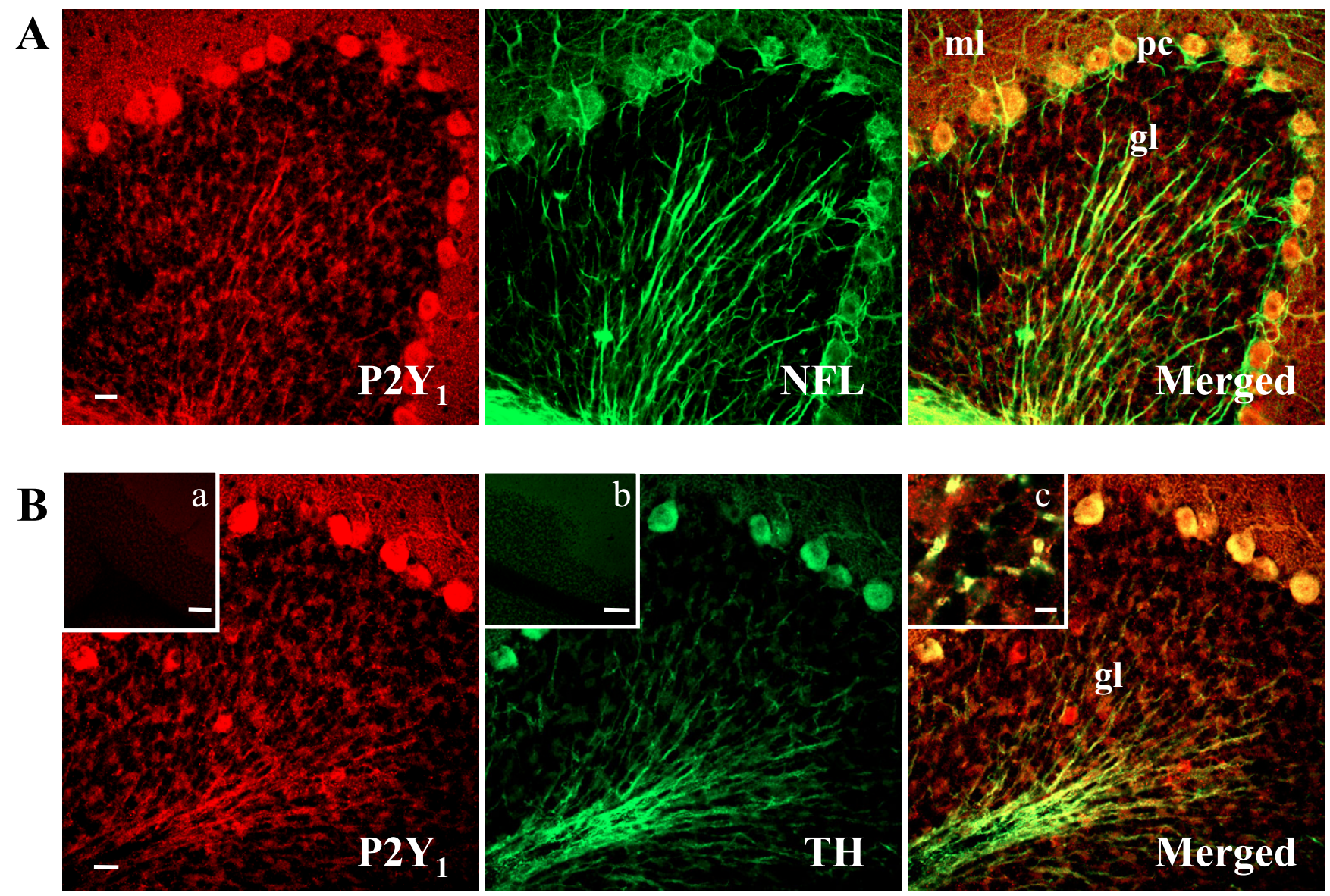

Figure 2

Localization of $\mathbf{P 2 Y}$, receptor on neurons. Confocal images demonstrate that P2Y, receptor immunoreactivity (red Cy3 immunofluorescence) colocalizes with NFL (green Cy2 immunofluorescence) specific for neuronal processes (A) and with TH (green Cy2 immunofluorescence) (B). The insets "a" and "b" in B, represent immunofluorescence analysis performed in the absence of the primary antibodies and only with the anti-rabbit or anti-mouse secondary antibodies, respectively. The inset "c" in B, shows large ( $1-3 \mu \mathrm{m}$ diameter) varicosities present on TH-positive fibers expressing P2Y, receptor (yellow immunofluorescence). Abbreviations: $\mathrm{ml}$, molecular layer; Pc, Purkinje cells; gl, granule layer. Scale bars are: $20 \mu \mathrm{m}$ in A and B; $100 \mu \mathrm{m}$ in the insets "a, b" in B; $5 \mu \mathrm{m}$ in the inset "c" in B.

and detected by the anti-myc 9E10 antibody (data not shown).

Since fluorescence microscopy also demonstrated a high degree of co-localization between $\mathrm{P}_{2} \mathrm{Y}_{1}$ receptor and synaptophysin (Fig. 4), fractions were also prepared directly from cerebellar synaptosomes, in order to confirm the synaptic localization of lipid rafts-resident $\mathrm{P}_{2} \mathrm{Y}_{1}$ receptor. Our results again demonstrate that only the $\mathrm{P}_{2} \mathrm{Y}_{1}$ receptor oligomer is present in synaptosomal lipid rafts-enriched fractions (Fig 7C), together with the lipid rafts markers flotillin-2 and GM1ganglioside (fractions 4-7). Neither monomer nor oligomer receptor is instead detected in the high density synaptosomal fractions (fractions 10-12) containing transferrin receptor, a protein known to be excluded from lipid rafts microdomains.
The phenotypic expression of $P 2 Y$, receptor switches during cerebellar development

We next investigated the expression of $\mathrm{P} 2 \mathrm{Y}_{1}$ receptor at postnatal day 7 (P7), when the maturation of synapses is just taking place between granule neuron dendrites and fiber terminals [23], and the internal granular layer (igl) rapidly expands beneath the monocellular sheet of pc. With the only exception of calbindin-positive pc (Fig. 8A), we find that $\mathrm{P}_{2} \mathrm{Y}_{1}$ receptor localization is completely different from that observed at P21 (Fig. 8A, inset). At P7, $\mathrm{P} 2 \mathrm{Y}_{1}$ receptor immunoreactivity is indeed absent from noradrenergic fibers of white matter, but predominantly shown: a) on fibers irradiating the thin $\mathrm{ml}$ (above the $\mathrm{pl}$ ) and the external granule (or germinal) layers (egl) (Fig. $8 \mathrm{~B})$; b) on cell bodies aligned at the interface between the pc and $\mathrm{ml}$ (Fig. 8B, upper-left inset); c) on isolated cells 

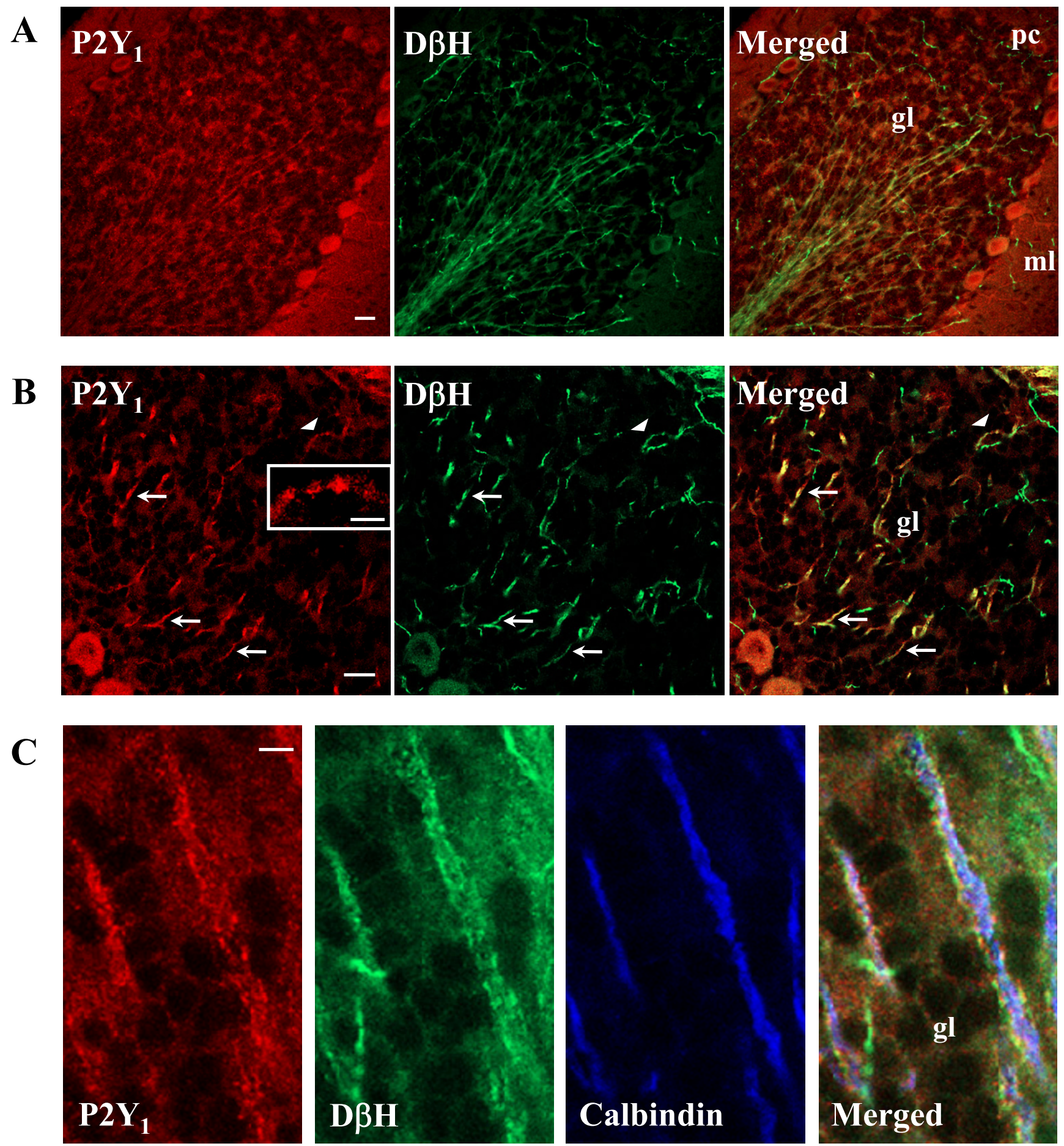

Figure 3

Localization of $\mathbf{P} 2 Y_{1}$ receptor on $D \beta H$ neurons. Confocal images demonstrate that $P 2 Y_{1}$ receptor immunoreactivity (red Cy3 immunofluorescence) colocalizes with $\mathrm{D} \beta \mathrm{H}$, specific marker of noradrenergic neurons (green Cy2 immunofluorescence). In panel B, a higher magnification of sparse and unbundled noradrenergic fibers of different thickness (arrows) and beaded nature (arrow head and inset) is shown. Panel $\mathrm{C}$ represents a triple immunofluorescence performed with anti-P2Y, receptor (red Cy3 immunofluorescence), anti-D $\beta \mathrm{H}$ (green Cy2 immunofluorescence), and anti-Calbindin-D-28K (blue immunofluorescence) antibodies. Scale bars are: $20 \mu \mathrm{m}$ in $\mathrm{A}$ and $\mathrm{B}$, and $5 \mu \mathrm{m}$ in $\mathrm{C}$ and in the inset in $\mathrm{B}$. 

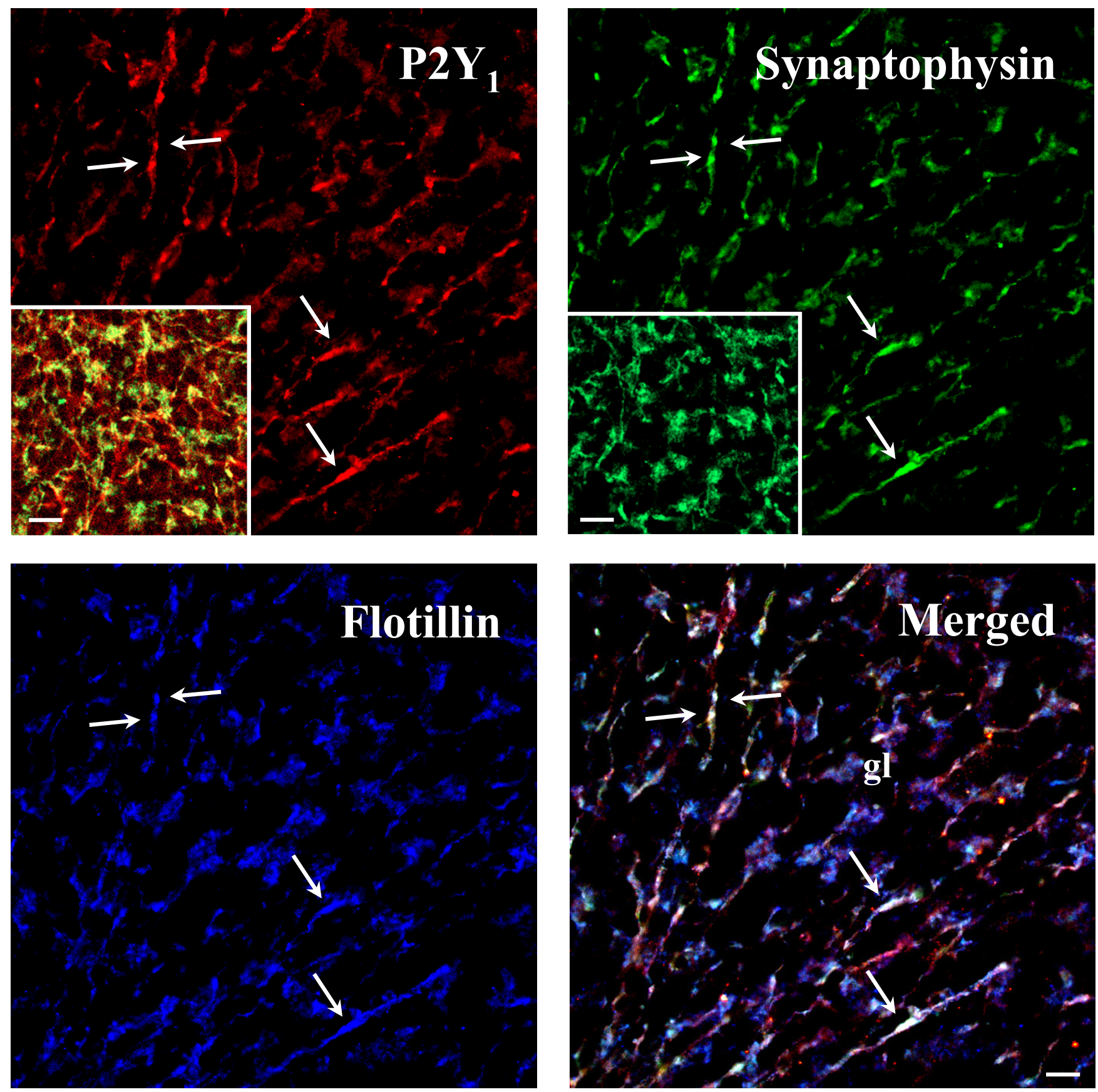

\section{Figure 4}

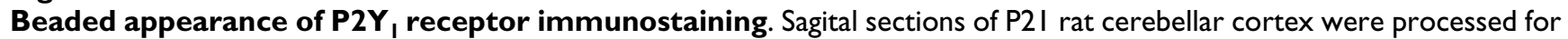
triple immunofluorescence analysis and visualized by confocal microscopy. Rabbit anti-P2Y, (red Cy3 immunofluorescence) was used in combination with mouse anti-synaptophysin, a marker for synaptic structures (green Cy2 immunofluorescence), and mouse anti-flotillin, a lipid rafts-associated integral membrane protein (blue immunofluorescence). In gl, the overlapping immunoreactive signals of $\mathrm{P} 2 \mathrm{Y}_{1}$, synaptophysin and flotillin (arrows) can be distinguished by white immunofluorescence (arrows). Scale bars: $10 \mu \mathrm{m}$ and $20 \mu \mathrm{m}$ in the insets.

located in the igl (Fig. 8B). $\mathrm{P} 2 \mathrm{Y}_{1}$ receptor immunostaining is thus totally absent from NFL-positive (Fig. 8C) and THor $\mathrm{D} \beta \mathrm{H}$-positive fibers (data not shown), which already span into the gl at this age of development. By means of distinctive morphology of cerebellar astrocytes and positive colocalization between $\mathrm{P}_{2} \mathrm{Y}_{1}$ receptor and GFAP (Fig. 

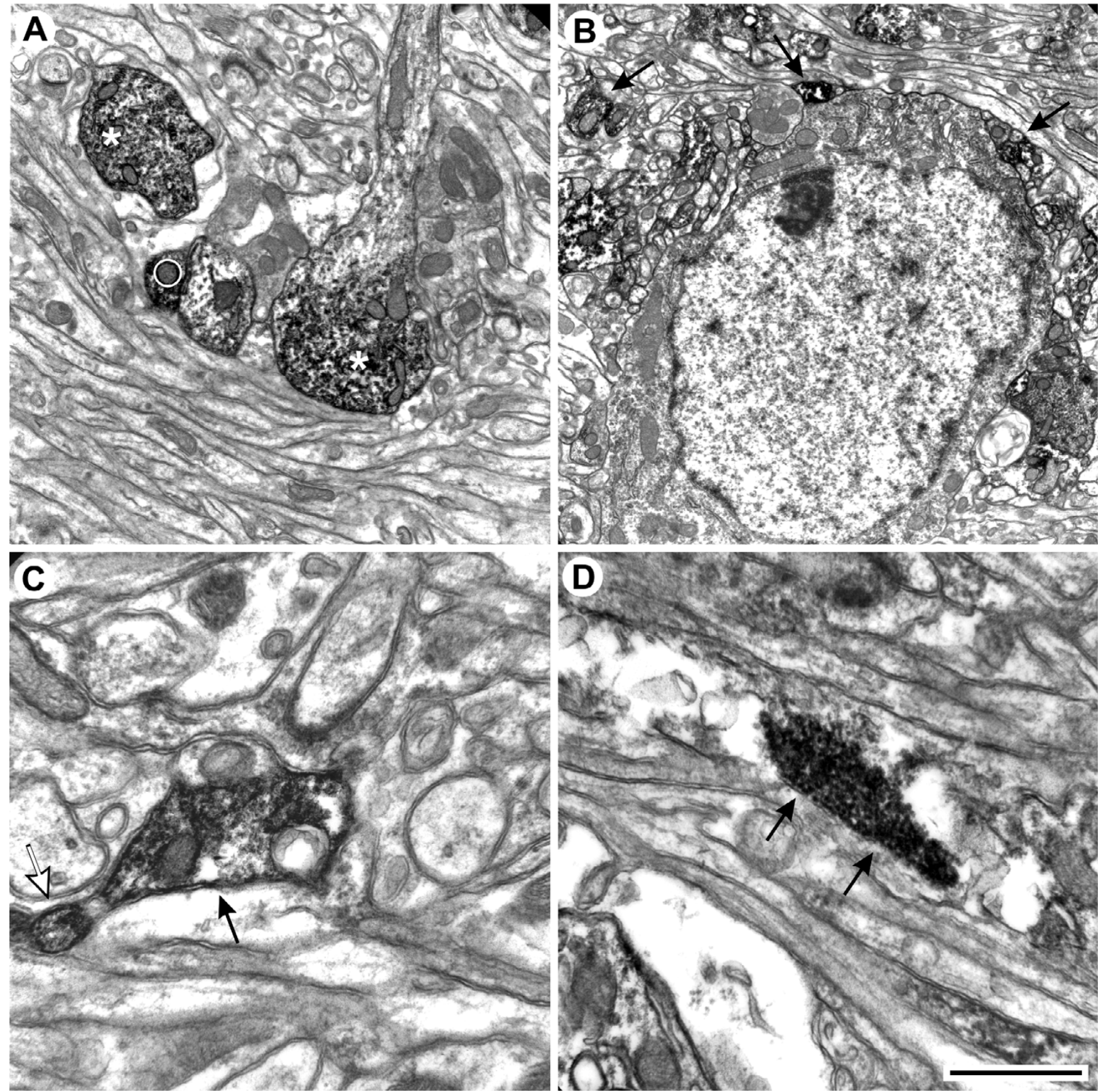

Figure 5

Electron microscopy analysis of $\mathbf{P} 2 Y_{\text {, }}$ receptor on both axon terminals and dendrites. In $A$, $P 2 Y$, receptor immunolabelling is shown on varicosities of fibers (white circle) and dendrites of granule cells (white asterisks). In B, P2Y, receptor immunolabelled varicosities (black arrows) are shown apposed to neuronal elements such as dendrites and cell bodies. In $\mathrm{C}$, P2Y, receptor immunolabelled varicosity (black arrow) contains mitochondria and pleomorphic vesicles, whereas the intervaricose segment (white arrow) is deprived of vesicles. In $D$, the varicosity is shown to be filled with pleomorphic vesicles, without forming a clear synaptic contact. Scale bars $=2 \mu \mathrm{m}$ in $A ; 2,5 \mu \mathrm{m}$ in $\mathrm{B} ; \mathrm{I} \mu \mathrm{m}$ in $\mathrm{C}$ and $\mathrm{D}$.

8B), at P7 we do identify $\mathrm{P}_{2} \mathrm{Y}_{1}$ receptor on both Bergmann cell bodies/fibers and astroglial cells scattered among granule neurons. This is confirmed for postnatal day one (data not shown), but is the opposite of what was shown at P21, when $\mathrm{P} 2 \mathrm{Y}_{1}$ receptor is totally absent from GFAPpositive structures (Fig. 8B, lower-right inset) and present 

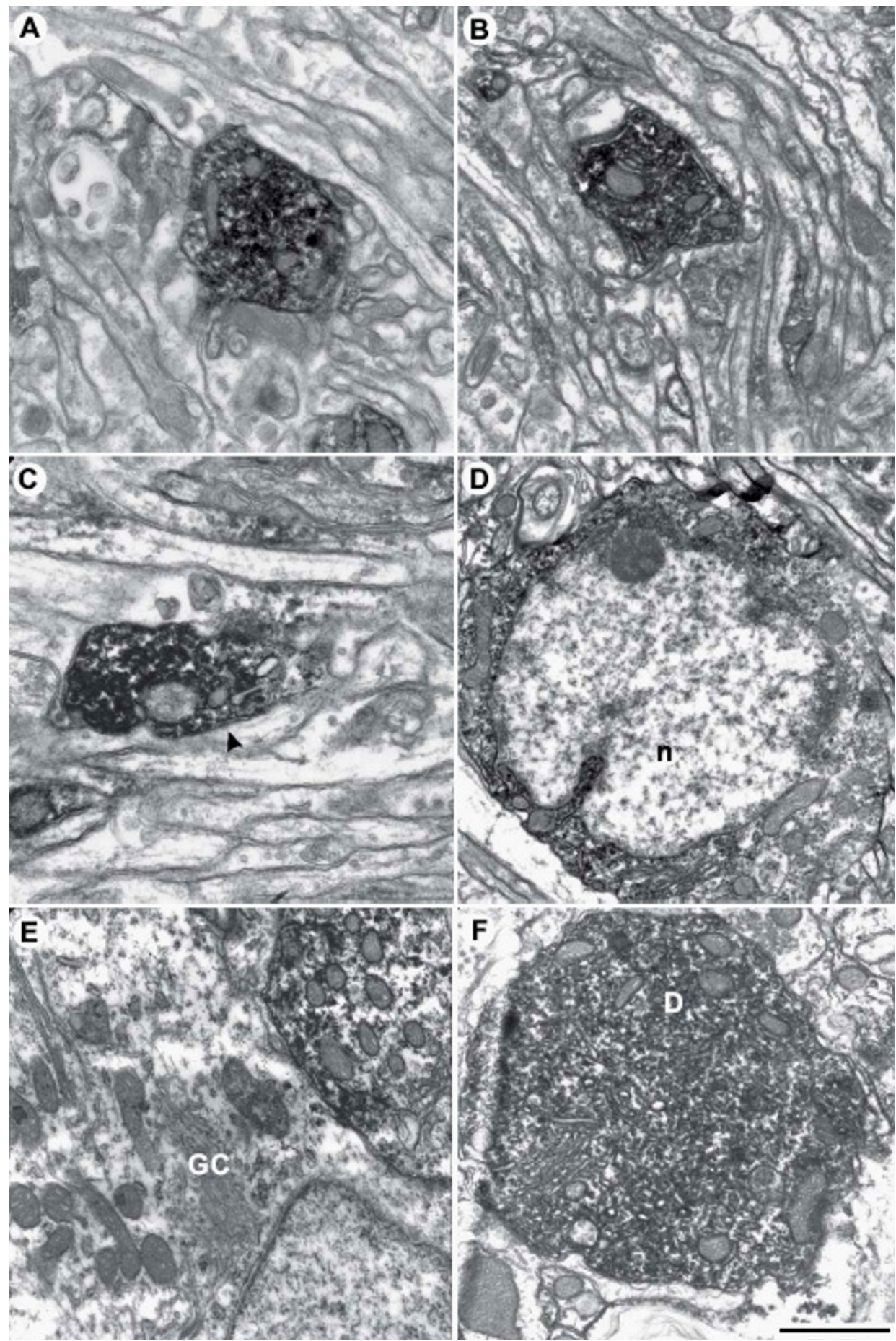

Figure 6

Electron microscopy analysis of $\mathbf{P} 2 Y$, receptor on synaptic terminals forming varicosities. In $\mathrm{A}$, labelled varicosities are apposed to neuronal elements of cerebellar cortical layers, mostly dendrites in granule cell layer. In a few cases, the immunoreactivity is so strong to cover the vesicles of the terminal. In $\mathrm{B}$, the features of the varicosities are unchanged also in Purkinje cell layer. In $C$, the absence of synaptic junctions is clearly visible (see arrow). In $D$, the granule cell shows specific labelling in the cytoplasm ( $\mathrm{n}=$ nucleus of granule cell). In $\mathrm{E}$, a few granule cells (GC) are labeled, being on the contrary apposed to immunolabeled terminals. In F, also Purkinje neurons are immunolabeled, especially proximal dendrites (D). Scale bar in A-C $=\mathrm{I} \mu \mathrm{m}$; in $\mathrm{D}=\mathrm{I}, 2 \mu \mathrm{m}$; in $\mathrm{E}$ and $\mathrm{F}=0,8 \mu \mathrm{m}$. 

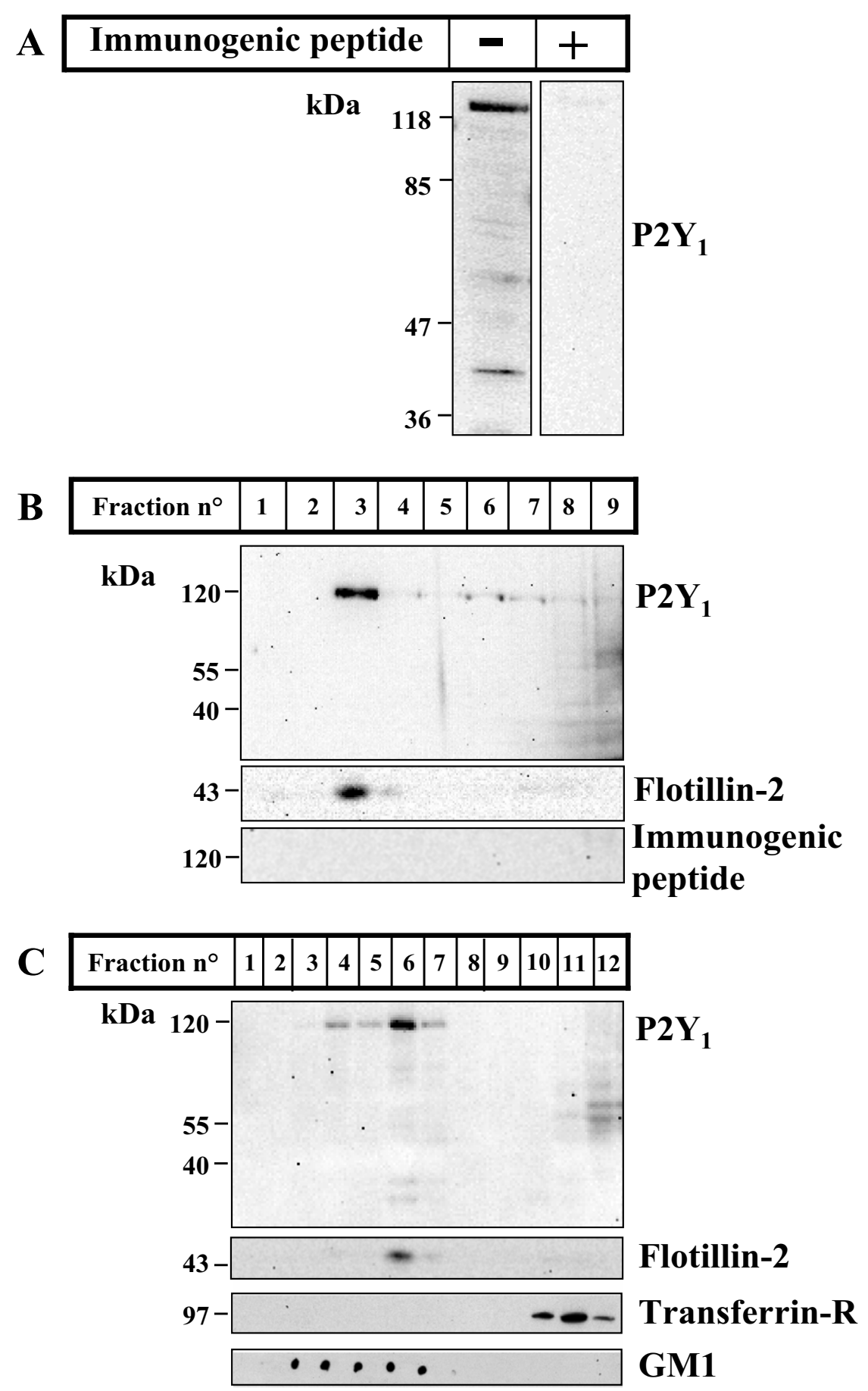

\section{Figure 7}

P2Y, receptor localizes in lipid rafts. Cerebella were removed from P2I rats and cell protein extracted in lysis buffer for $30 \mathrm{~min}$ on ice. Supernatants obtained after a centrifugation for $10 \mathrm{~min}$ at $15000 \times \mathrm{g}$ were loaded on SDS-PAGE (I00 $\mu \mathrm{g} / \mathrm{lane})$, transferred to nitrocellulose and probed with anti-P2Y, receptor antiserum, in the absence (-) or presence $(+)$ of the immunogenic peptide (A). Lipid rafts-enriched fractions were then prepared from total cerebellar tissue (B) or from purified cerebellar synaptosomes (C), both obtained from $\mathrm{P} 2 \mathrm{I}$ rats. $\mathrm{P} 2 \mathrm{Y}$, receptor is recovered in rafts fractions 3 (B), in the absence of the immunogenic peptide, or 4-7 (C), together with the selective lipid rafts markers flotillin-2 (B, C) or GMI (C), but not the transferrin receptor $(C)$, a protein known to be excluded from lipid microdomains. 
only on neuronal fibers (Figs. 2, 3, 4). Conversely, the enrichment of $\mathrm{P}_{2} \mathrm{Y}_{1}$ receptor in lipid rafts, but not synaptosomal fractions, is confirmed also at P7 (data not shown), therefore appearing as a conserved feature of this receptor.

It's well known that, during development, Bergmann fibers are associated with migrating granule cells, from which is derived the concept of glia-guided neuronal migration [24], and that DCX is a distinctive marker of granule cells only during the period of radial descent into the deep cerebellar layers, when it directs neuronal movement through the organization and stability of microtubules [25]. Therefore, we used DCX immunoreactivity to observe the potential relationship between Bergmann glia (P2Y $\mathrm{Y}_{1}$-positive only at neonatal ages $\left.\mathrm{P} 1-\mathrm{P} 7\right)$ and granule neurons. We find that at P7, the DCX-positive signal appears as a diffuse labeling on both the entire igl and the thin $\mathrm{ml}$ enriched in radially migrating granule cells, but is excluded by the pre-migratory $\mathrm{P}_{2} \mathrm{Y}_{1}$-expressing egl (Fig. 9A). Given the high density, amoeboid shape and lack of defined neuronal contour of migrating granule cells at this neonatal age, the DCX-positive staining appears contiguous to $\mathrm{P}_{2} \mathrm{Y}_{1}$-GFAP fibers (Fig. 9A inset), providing an almost overlapping signal when observed at low magnification (Fig. 9A, yellow fluorescence). Nevertheless, at higher resolution it is possible to distinguish that DCXpositive granule cells are wrapped up and stretched along P2Y 1 -GFAP-positive Bergmann fibers (Fig. 9A inset). On the opposite, when at P21 the egl almost disappears after complete proliferation and migration of granule neurons [23], the DCX immunostaining is confined to a very narrow zone below the $\mathrm{pc}$ (Figs. 9B, inset) and $\mathrm{P}_{2} \mathrm{Y}_{1}$ receptor is no longer detected on Bergmann glia (Fig. 8B lowerright inset and Fig. 9B).

\section{Discussion}

The main goal of our study was to characterize the cellular and subcellular distribution and features of the purinergic metabotropic $\mathrm{P} 2 \mathrm{Y}_{1}$ receptor in the cerebellum, and to gain insights on its potential function during development of the cerebellar circuitry. To this purpose, we analyzed $\mathrm{P} 2 \mathrm{Y}_{1}$ receptor expression at $\mathrm{P} 21$, when the major structural changes already took place in the developing cerebellum, and compared it with expression at P7, when migration of granule neurons from the molecular to the granular layer is still occurring $[23,26,27]$, and when the neuronal bodies in the locus coeruleus of origin for the dorsal bundle of noradrenergic neurons innervating the cerebellum are spreading out their projections to the granular, Purkinje and molecular layers [28]. In juvenile rat cerebellum we find that, in addition to Purkinje cell bodies and ramifications [12], $\mathrm{P}_{2} \mathrm{Y}_{1}$ receptor is abundant on neuronal specializations identified as noradrenergic by anatomical (the fibers travel in linear, sparse and different thickness pro- files through the gl, and branch into radially and longitudinally oriented chains), ultrastructural (abundance of synaptic varicosities and winding, beaded appearance) and biochemical features (immunoreactivity with noradrenergic-specific $\mathrm{D} \beta \mathrm{H}$ absent from Purkinje neurons in rat) [29]. Moreover, we observe that $\mathrm{P} 2 \mathrm{Y}_{1}$ receptor is preferentially localized on synaptic varicosities of the noradrenergic fibers and synaptic glomeruli, which can be recognized by the presence of synaptophysin. The ultrastructural analysis confirms the localization of $\mathrm{P}_{2} \mathrm{Y}_{1}$ receptor on varicosities of axon terminals, moreover showing features indicative of a particular modality of transmitter release. As generally reported for noradrenergic fibers [30], the absence of conventional synaptic junctions led us to suppose that in the cerebellum also extracellular nucleotides might exert their modulatory action through paracrine release or simple diffusion in the extracellular space. This modality has the advantage to extend the potential effects of extracellular nucleotides, and neurotransmitters in general, to structures equipped with adequate receptors (extra-synaptic receptors) [31], but distant from the source of release (volume transmission) [32]. The enrichment in these $\mathrm{P}_{2} \mathrm{Y}_{1}$-positive varicosities of both synaptophysin and the lipid rafts marker flotillin-2 (together with the biochemical observation that $\mathrm{P}_{2} \mathrm{Y}_{1}$ receptor is indeed a lipid rafts-resident protein in total cerebellar tissue and cerebellar synaptosomes) furthermore suggests that the role of $\mathrm{P}_{2} \mathrm{Y}_{1}$ receptor is likely mediated by lipid microdomains. In this regard, it is already well-known that lipid rafts display a key part in the targeting and functional organization of proteins at both synapses and spines [33].

Since a further specification of the central noradrenergic system consists in the frequency of co-transmission phenomena, the presence in the cerebellum of $\mathrm{P} 2 \mathrm{Y}_{1}$ receptor on noradrenergic neurons in addition to Purkinje cells might signify that extracellular nucleotides such as the natural agonists ATP and ADP could contribute in this brain region to the physiological role of noradrenaline [34]. In this regard, ATP is already well known to be coreleased with noradrenaline in various PNS and CNS neurons [35,36]. Thus, if co-release and synergism occur at cerebellar synapses as well, nucleotide-dependent increase of cerebellar noradrenergic signaling could be achieved. Homologous recombination techniques have shown that complete removal of either the enzymes responsible for noradrenaline metabolism or the vesicular monoamine transporter has deleterious consequences for foetal survival [37]. Moreover, blockade of postsynaptic noradrenergic receptors decreases the rate of learning in several cerebellar-dependent motor tasks [38]. The possibility of integrating and complementing noradrenergic with purinergic mechanisms to increase the strength of synaptic connections through activation of both 


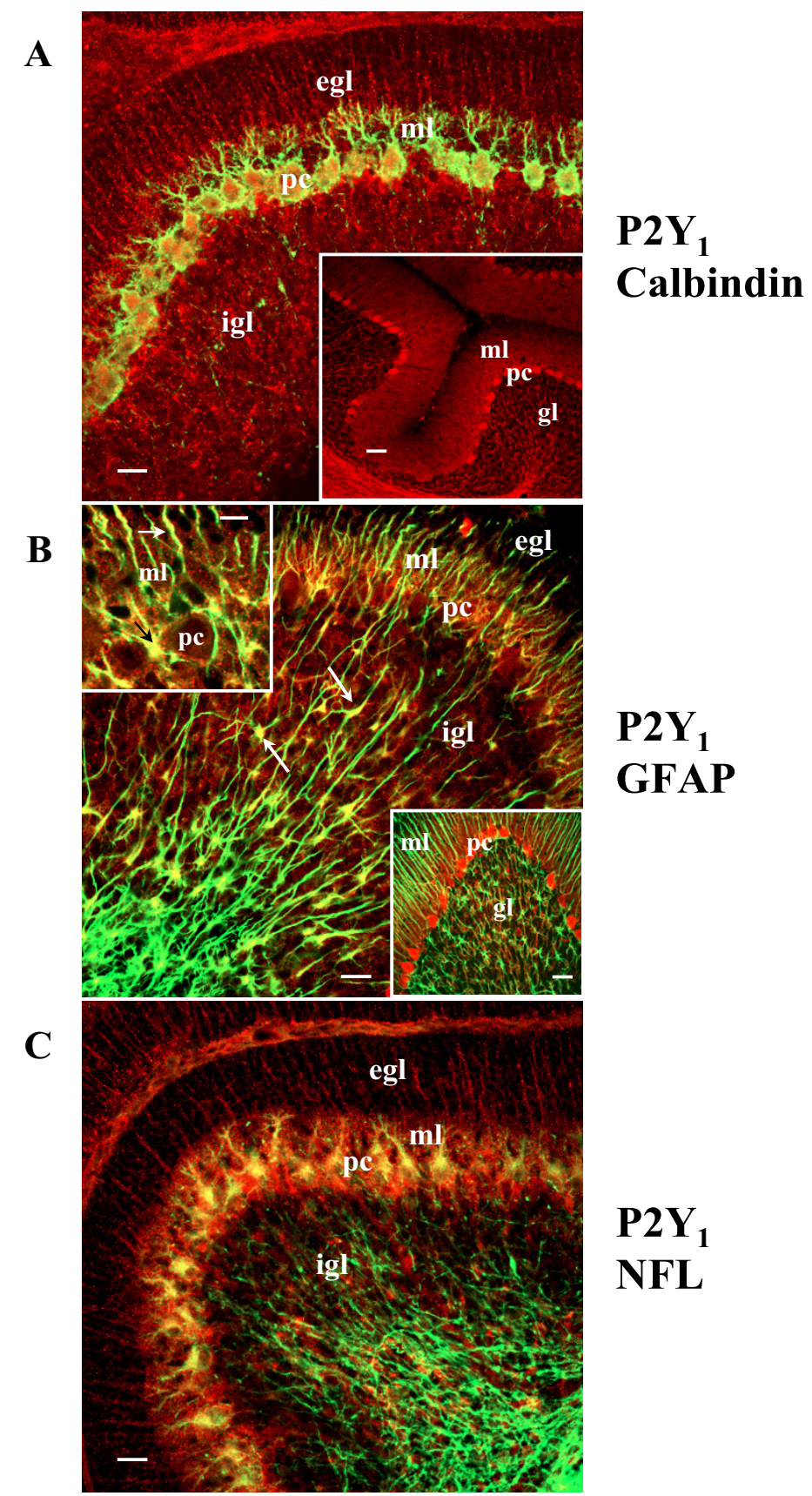

\section{Figure 8}

Map of $\mathbf{P 2 Y}$, receptor protein in neonatal versus juvenile rat cerebellar cortex. Double immunofluorescence visualized by confocal analysis was performed in neonatal rat (P7) cerebellar cortex and compared to that at P2I (inset in panel A). At P7, P2Y, receptor immunoreactivity (red Cy3 immunofluorescence) is present on calbindin-positive pc (green Cy2 immunofluorescence), on fibers irradiating from the thin $\mathrm{ml}$ toward the egl $(A, B)$, on cell bodies at the interface between the pl and $\mathrm{ml}$ (black arrow in the left inset of panel B), and on isolated cells situated in the igl (white arrows in panel B). Double immunofluorescence (yellow) shows complete colocalization between P2Y, (red Cy3 immunofluorescence) and GFAP (green Cy2 immunofluorescence) signals (white arrows in B; black and white arrows in the upper-left inset of panel B), differently from what observed at P2I (lower-right inset of panel B). In C, P2Y, (red Cy3 immunofluorescence) and NFL (green Cy2 immunofluorescence) immunostaining are shown. Abbreviations: egl, external granule layer; gl, granule layer; igl, internal granule layer; $\mathrm{ml}$, molecular layer; pc, Purkinje cells. Scale bar $=20 \mu \mathrm{m}$ in A, B and C; $50 \mu \mathrm{m}$ in the inset in A; $10 \mu \mathrm{m}$ in the upper-left inset in $\mathrm{B} ; 40 \mu \mathrm{m}$ in the lower-right inset in B. 


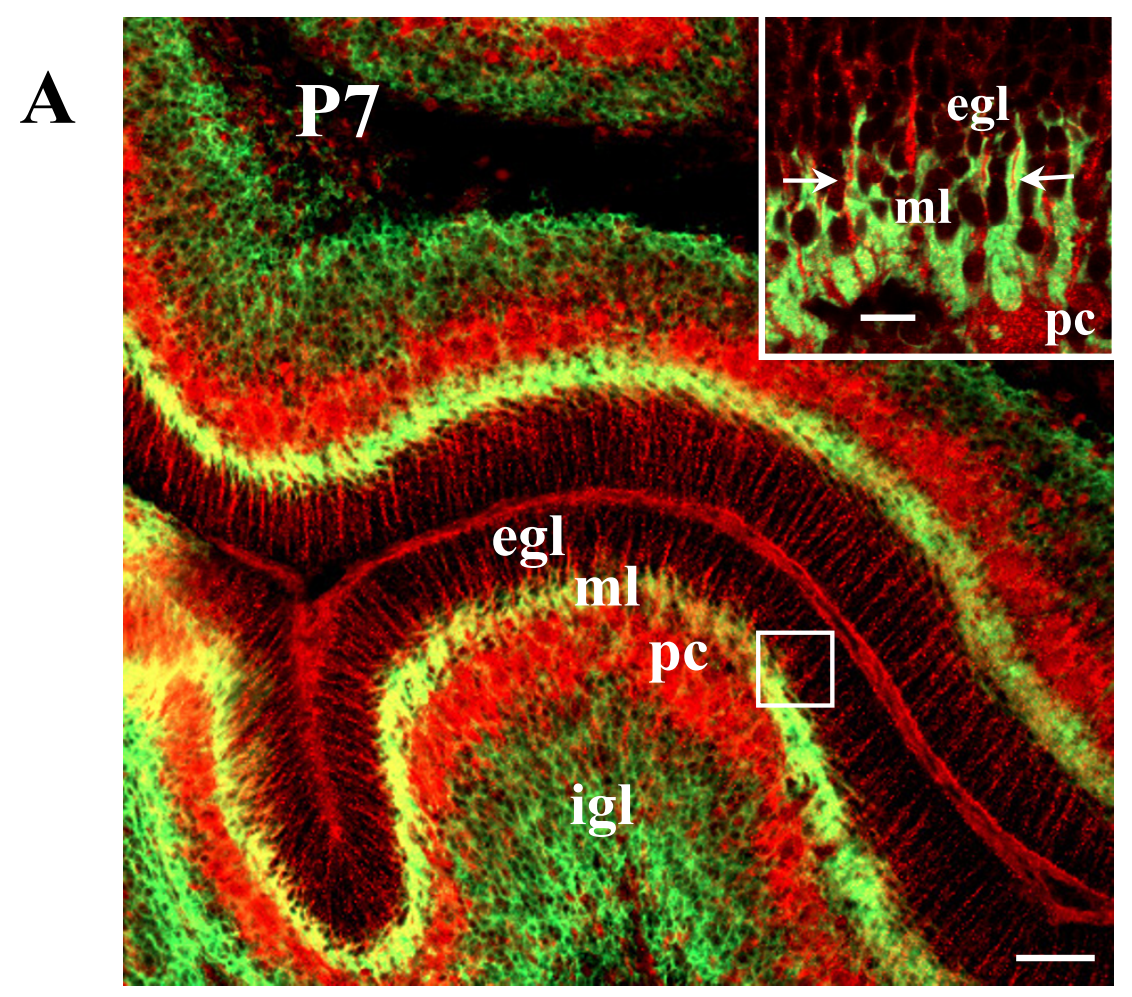

\section{$\mathrm{P}_{1} \mathrm{Y}_{1}$ DCX}

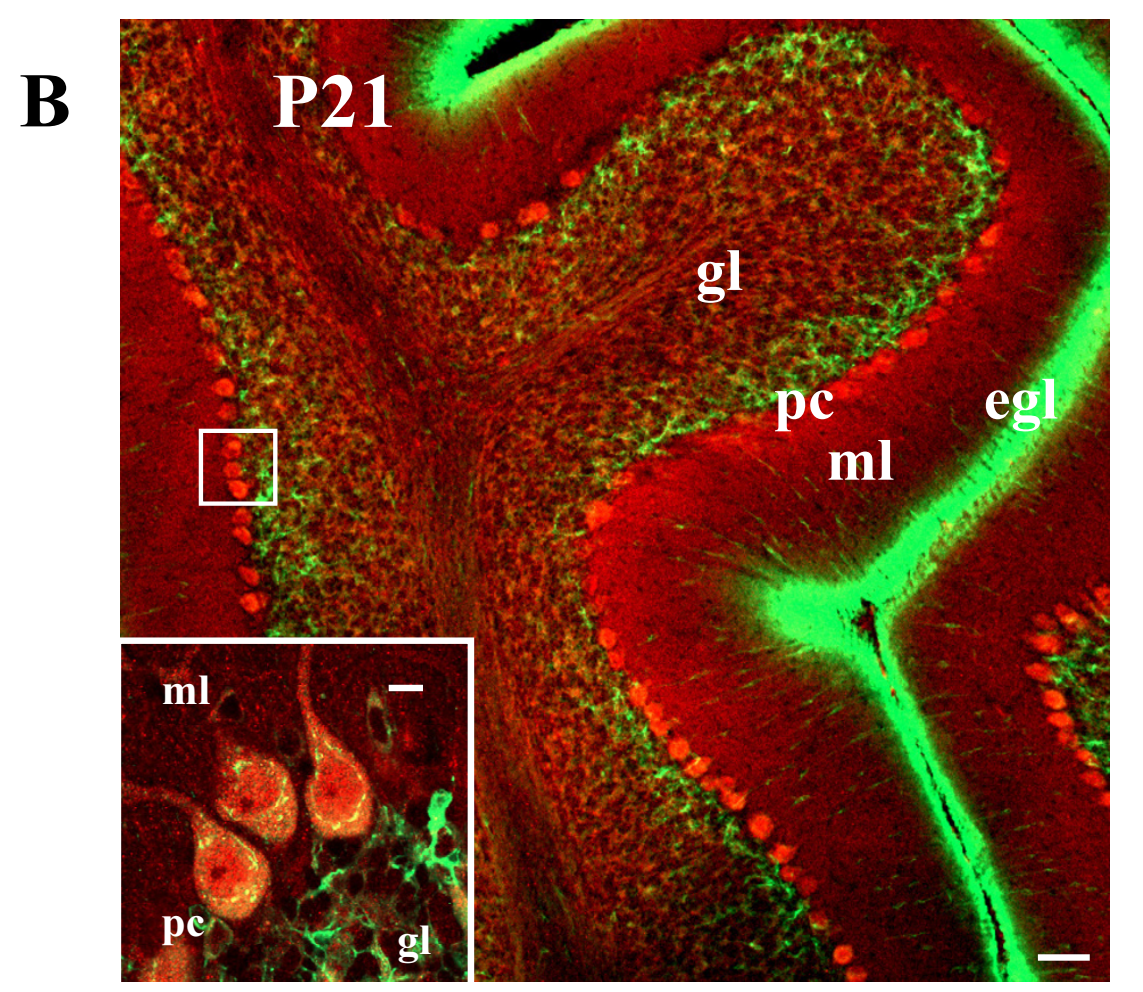

P2Y
DCX

Figure 9

P2Y, receptor and migrating granule neurons. Confocal images of DCX (green Cy2 immunofluorescence) and $P 2 Y_{1}$ (red Cy3 immunofluorescence, white arrows in the inset of panel A) are shown from cerebellar cortex of neonatal rat at P7 (A) and P2I (B). Abbreviations: egl, external granule layer; gl, granule layer; igl, internal granule layer; ml, molecular layer; pc, Purkinje cells. Scale bar $=50 \mu \mathrm{m}$ in $A$ and $B ; 10 \mu \mathrm{m}$, in the inset in $A$ and $B$. 
noradrenergic and $\mathrm{P}_{2} \mathrm{Y}_{1}$ receptors might therefore constitute also a novel powerful approach against neuronal degeneration and/or malfunctioning in the cerebellum.

The presence of $\mathrm{P} 2 \mathrm{Y}_{1}$ receptor in postnatal rat cerebellum was then analyzed before the formation of noradrenergic synaptic connections takes place. Surprisingly, we have shown here that $\mathrm{P}_{2} \mathrm{Y}_{1}$ undergoes a drastic switch during development, with a phenotypic expression resembling that of Bergmann glia at P7, rather then noradrenergic neurons at P21. In this regard, it is well established that a number of neuronal and glial receptor systems and/or diffusible factors act to induce and maintain Bergmann glia process extension at an early stage of postnatal development [39-41], when Bergmann cells specialize in supporting the migration of granule neurons and migration of granule cells seems to be largely dependent on their interaction with glial processes $[42,43]$. In particular, the ErbB4 tyrosine kinase receptor present on Bergmann glia appears to have a distinct role in this process [44], interacting with neoregulin expressed on migrating granule cells $[45,46]$. On the other hand, in vitro studies on the migration of granule neurons demonstrated that the glycoprotein astrotactin provides a neuronal receptor system for migration along glial processes [47]. Thus, $\mathrm{P} \mathrm{Y}_{1}$ receptor expression only on Bergmann glia at an early stage of development might sustain a role for purinergic receptors in signaling events needed for interaction and migration of neurons. This is strongly supported by the result that $\mathrm{ADP}$, preferential ligand for $\mathrm{P}_{2} \mathrm{Y}_{1}$ receptor, induces $\mathrm{Ca}^{2+}$ mobilization in Bergman glia [48]. The factors produced by granule neurons to induce the glial scaffold might thus comprise the purinergic ligands ATP and ADP directly targeting $\mathrm{P}_{2} \mathrm{Y}_{1}$ receptors. To support this hypothesis, we have both shown here that $\mathrm{P}_{2} \mathrm{Y}_{1}$ receptor is localized at the interface between Bergmann glia and DCX-positive migrating granule cells, and previously demonstrated that, at least in vitro, granule neurons can release ATP, which is easily degraded to ADP in the extracellular environment [49]. It is finally well known that, once migration across the glia scaffold is completed and cells change their repertoire of adhesive molecules and switch into a static asset: a) the Bergmann glia loses the apposition with granule neurons; b) the granule cells are locked in position by the formation of new specific axon-target interactions [46]. In parallel, we have demonstrated here that in juvenile rat cerebellum: a) the Bergmann glia lose P2Y receptors; b) $\mathrm{P}_{2} \mathrm{Y}_{1}$ receptors appear on Purkinje and noradrenergic neurons forming new specific axon-target interactions.

\section{Conclusion}

Since membrane components of the cell surface are largely known to mediate the close apposition between two cells during all phases of development, our results suggest a novel role for $\mathrm{P}_{2} \mathrm{Y}_{1}$ receptor in the CNS, specifically in cell junction/communication. This already occurs on platelets, where $\mathrm{P} 2 \mathrm{Y}_{1}$ receptor is well known to mediate cell contact and aggregation [50-52]. Considering the glia-neuron switch of $\mathrm{P}_{2} \mathrm{Y}_{1}$ receptor a novel biological mechanism of development, aim of further studies will be to investigate the potential impact of this receptor on Bergman glia-guided migration of granule neurons; on alteration/reorganization of noradrenergic fibers in the cerebellar cortex in response to the degeneration of their major target, granule and Purkinje neurons; and finally to investigate if the presence of purinergic ligands in the environment surrounding noradrenergic fibers can influence their anatomical integrity and development.

\section{Methods Histological procedures}

Wistar rats (Harlan, Udine, Italy) of different ages were deeply anesthetized by i.p. injections of sodium pentobarbital $(60 \mathrm{mg} / \mathrm{kg})$, and transcardially perfused with saline $(0.9 \% \mathrm{NaCl})$ followed by $4 \%$ paraformaldehyde, in phos-

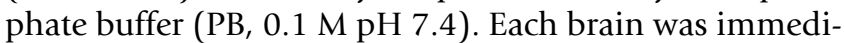
ately removed, post-fixed in the same fixative for $2 \mathrm{hs}$, and then transferred to $30 \%$ sucrose in $\mathrm{PB}$ at $4{ }^{\circ} \mathrm{C}$, until it sank. The experimental protocol used in this study was approved by the Italian Ministry of Health and was in agreement with the guidelines of the European Communities Council Directive of November 24, 1986 (86/609/ EEC) for the care and use of laboratory animals. All efforts were made to minimize the number of animals used and their suffering.

\section{Double immunofluorescence}

Sagital sections $(40 \mu \mathrm{m}$ thick) were cut on a freezing microtome and were processed for double immunofluorescence studies. Non-specific binding sites were blocked with $10 \%$ normal donkey serum in $0.3 \%$ Triton X-100, in phosphate buffered saline (PBS) for $30 \mathrm{~min}$ at room temperature. The sections were incubated in a mixture of primary antisera for $24 \mathrm{hs}$ in $0.3 \%$ Triton X-100 in PBS. Rabbit anti-P2Y 1 (1:500, Alomone, Jerusalem-Israel) was used in combination with either mouse anti-CalbindinD-28K (1:200, Sigma, Mi-Italy), mouse anti-Tyrosine Hydroxylase (TH, 1:500, Sigma), mouse anti-Dopamine $\beta$-Hydroxylase $(\mathrm{D} \beta \mathrm{H}, 1: 500$, Chemicon International, Inc. Temecula, CA-USA), mouse anti-Glial Fibrillary Acidic Protein (GFAP) (1:400, Sigma), mouse anti-Synaptophysin (1:100, Sigma), goat anti-Doublecortin (DCX, 1:200, Santa Cruz, Mi-Italy), or goat anti-NFL (Neurofilament-L protein, 1:100, Santa Cruz). The secondary antibodies used for double labeling were Cy3-conjugated donkey anti-rabbit IgG (1:100, Jackson Immunoresearch, West Baltimore Pike, PA, USA, red immunofluorescence), Cy2-conjugated donkey anti-mouse IgG (1:100, Jackson Immunoresearch, green immunofluorescence) or $\mathrm{Cy} 2$ - 
conjugated donkey anti-goat IgG (1:100, Jackson Immunoresearch, green immunofluorescence). The sections were washed in PBS three times for five min each, and then incubated for 3 hs in a solution containing a mixture of the secondary antibodies in 1\% normal donkey serum in PBS. After rinsing, the sections were mounted on slide glasses, allowed to air dry and coverslipped with gel/ mount $^{\mathrm{TM}}$ anti-fading medium (Biomeda, Foster City, CAUSA).

\section{Triple immunofluorescence}

After double immunofluorescence, the sections were mounted on slide glasses, and allowed to air dry. A rectangle was then drawn around the sections with a PAP pen. To allow the use of a second mouse antibody in the same immunolabeling protocol, the unlabeled monoclonal anti-NeuN (Neuronal Nuclei, mouse IgG $_{1}$ isotype or antiCalbindin-D-28K (mouse IgG $_{1}$ isotype)) or Flotillin-2 (mouse IgG $_{1}$ isotype) were labeled with Zenon technology (Molecular Probes, Oregon, USA). Briefly, mouse anti-NeuN (1:100, Chemicon International), mouse antiFlotillin-2 (1:100, BD Biosciences, San José, CA) and mouse anti-Calbindin-D-28K (1:200, Sigma) were separately incubated with Zenon Alexa Fluor 647 mouse IgG $_{1}$ labeling reagent (molar ratio 6:1), which contains a fluorophore-labeled (Ex/Em 650/668) anti-mouse Fab fragments. The labeled Fab fragments bind to the Fc portion of the monoclonal antibodies and excess Fab fragments are neutralized by the addition of a nonspecific IgG (Zenon blocking reagent-mouse $\mathrm{IgG}$ ). The addition of non-specific IgG prevents cross-labeling of the Fab fragment, in experiments where multiple primary antibodies of the same type are present. After rehydration in PBS, the sections were incubated with the staining solution in PBS containing $0.5 \%$ Triton X-100 (PBT) in a humidified chamber for 2 hs at room temperature. The sections were washed twice in PBT and for $5 \mathrm{~min}$ in PBS at room temperature. Sections were then fixed in $4 \%$ paraformaldehyde in PB for $15 \mathrm{~min}$ at room temperature, to avoid the dissociation of the Zenon Fab fragment from the primary antibody, washed three times with PBS, allowed to air dry and coverslipped with gel/mount anti-fading medium.

\section{Confocal microscopy}

Double or triple label immunofluorescence was analyzed by means of a confocal laser scanning microscope (CLSM) (LSM 510, Zeiss, Arese Mi-Italy) equipped with argon laser emitting at $488 \mathrm{~nm}$, helium/neon laser emitting at $543 \mathrm{~nm}$, and helium/neon laser emitting at $633 \mathrm{~nm}$. Specificity of the antibodies was positively proved by performing confocal analysis in the absence of the primary antibodies, but in the presence of either anti-rabbit or anti-mouse secondary antibodies. Specificity was further confirmed for the $\mathrm{P}_{2} \mathrm{Y}_{1}$ antiserum by performing immu- noreactions in the simultaneus presence of the $\mathrm{P} 2 \mathrm{Y}_{1}$ neutralizing immunogenic peptide.

\section{Electron microscopy sample preparation}

Rats $(\mathrm{n}=4)$ were anaesthetised with chloral hydrate (400 $\mathrm{mg} / \mathrm{kg}$ i.p.), perfused through the ascending aorta with a solution of $\mathrm{NaCl} 0.9 \%$ for $5 \mathrm{~min}$, then followed by $3 \%$ paraformaldehyde with $0.4 \%$ glutaraldehyde in $\mathrm{PB}$ for 30 min. Cerebella were dissected and sagittal sections were cut at $40 \mu \mathrm{m}$, and washed several times in PBS. Sections were treated with sodium borohydrate (Sigma) $0.1 \%$ in PBS. Immunoreactivity for $\mathrm{P}_{2} \mathrm{Y}_{1}$ receptor was detected by means of the avidin-biotin peroxidase method. Briefly, sections from the cerebellum were pre-blocked in a solution containing 10\% goat serum in PB for $30 \mathrm{~min}$ at room temperature. Then, sections were incubated in a solution containing primary antibody against $\mathrm{P} 2 \mathrm{Y}_{1}$ receptor (rabbit anti-P2 $\mathrm{Y}_{1}$ diluted 1:200) in PB for 24 hs at $4^{\circ} \mathrm{C}$. After several washes in PBS, sections were incubated with biotinylated secondary antibody (goat anti-rabbit diluted 1:100 Vectastain Elite, Vector Laboratories, Peterborough, $\mathrm{UK}$ ) in PB for $3 \mathrm{hs}$ at room temperature. They were then incubated in avidin-biotin peroxidase complex (diluted 1:100 in PB; Vectastain Elite, Vector Labs.) for $1 \mathrm{~h}$. After washing, immunolabeling was revealed by incubation of the sections in $0.05 \%$ 3,3'-diaminobenzidine solution (DAB-Sigma) diluted in Tris- $\mathrm{HCl}$ buffer, in the presence of $0.01 \% \mathrm{H}_{2} \mathrm{O}_{2}$. The reaction was stopped by several washes in Tris-HCl buffer followed by PBS. Sections were postfixed in osmium tetroxide (1\% in $\mathrm{PB}$ ) for $10 \mathrm{~min}$, dehydrated in ascending series of dilution of ethanol (with the presence of $1 \%$ uranyl acetate in $70 \%$ ethanol) followed by propylene oxide (Aldrich, MI, Italy) and then embedded overnight in resin (Durcupan ACM-Fluka, Gillingham, Dorset, UK), mounted on glass slides and then cured at $60^{\circ} \mathrm{C}$ for $48 \mathrm{hs}$. The areas of interest were examined in the light microscope, cut from the sections and $60 \mathrm{~nm}$ ultra-thin sections were obtained with an ultramicrotome (Reichert-Jung Ultracut E, Leica, Nussloch, Germany), and collected on 400-mesh copper grids, counterstained with lead citrate and examined using a Zeiss EM900 electron microscope. Controls were performed omitting the primary antibody from the procedure.

\section{Electron microscopy data analysis}

The ultrastructural analysis was performed exclusively on the most superficial portions of the tissue in contact with the embedding plastic, in order to minimize artificial differences in labeling attributed to potential differences in the penetration reagents. Regions used for this analysis were chosen on the basis of $\mathrm{P} 2 \mathrm{Y}_{1}$ receptor immunoreactivity and the morphological integrity of the tissue. The labelled profiles were examined in thirty-two ultra-thin sections from three separate rats, in four sections each taken from the vermis, the cerebellar hemispheres and the 
cerebellar nuclei. Electron micrographs of immunoreactive structures were taken at magnifications of 7000$30000 \mathrm{X}$, then printed and used as the sampling region of each block. The classification of neuronal elements was made according to the description of Peters et al., [53]. Neuronal somata were identified by the nucleus, Golgi apparatus, and rough endoplasmic reticulum; un-myelinated axons were distinguished from dendrites by their larger diameter and/or the abundance of uniformly distributed microtubules and synaptic inputs from axon terminals. Neuronal profiles were classified as unmyelinated axons if they were $0.1-0.25 \mu \mathrm{m}$ in cross sectional diameter and contained microtubules and/or small vescicles. Axon terminals were defined as elements 0.25 $\mu \mathrm{m}$ or larger in diameter containing numerous small synaptic vescicles. Synapses formed by axon terminals were defined as asymmetric, when their post-synaptic density was thicker that the pre-synaptic one, and as symmetric, when both membranes showed equal electron density. Two structures were considered adjacent, when the two plasma membranes were parallel and not separated by glial processes, but no membrane specialization was visible.

\section{Preparation of low density membrane fractions}

Detergent-insoluble glycolipid fractions were prepared following an established method [54], with minor modifications [55]. Briefly, cerebella were removed from 21 days old Wistar rats, cut with a $\mathrm{M}_{\mathrm{c}}$ Ilwain tissue chopper $(400 \mu \mathrm{m})$ in two orthogonal directions and resuspended in 10 volumes $(\mathrm{w} / \mathrm{v})$ of ice-cold lysis buffer $(10 \mathrm{mM}$ Tris$\mathrm{HCl} \mathrm{pH} 7.5,150 \mathrm{mM} \mathrm{NaCl}, 1 \%$ Triton X-100, $2 \mathrm{mM}$ EDTA, $1 \mathrm{mM}$ PMSF, $20 \mu \mathrm{M}$ Leupeptin) by vortexing. After $30 \mathrm{~min}$, the lysate was centrifuged at $2000 \times \mathrm{g}$ for $10 \mathrm{~min}$, to remove nuclei and large debris. The resulting supernatant ( $500 \mu \mathrm{l}, 2-2.5 \mathrm{mg})$ was mixed with an equal volume

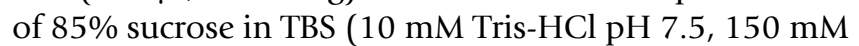
$\mathrm{NaCl}$ ), and placed at the bottom of the centrifuge tube. A volume of $700 \mu \mathrm{l}$ of $35 \%$ sucrose in TBS and $400 \mu \mathrm{l}$ of $5 \%$ sucrose were layered on the top of the lysate. The gradient was centrifuged for $14 \mathrm{hs}$ at $200.000 \times \mathrm{g}$ in a TLS 55 rotor (Beckman Instruments, Porterville, CA). Four fractions of $150 \mu \mathrm{l}$ and five fractions of $300 \mu \mathrm{l}$ were collected from the top of the tube. The entire procedure was performed at $4^{\circ} \mathrm{C}$. Equal volumes, containing a range of approximately $0.5-100 \mu \mathrm{g}$ of total protein depending on the fraction, were loaded on SDS-PAGE electrophoresis.

\section{Synaptosome Triton $X-100$ solubilization and sucrose floatation gradients}

Synaptosomes were obtained from rat cerebella by means of differential centrifugation, as previously described [56]. Briefly, post-nuclear supernatants were centrifuged at $9200 \times \mathrm{g}$ for $15 \mathrm{~min}$ to yield a pellet corresponding to partially purified synaptosomes. These pellets $(6 \mathrm{mg}$ of pro- teins) were resuspended in $0.75 \mathrm{ml}$ of buffer A ( $150 \mathrm{mM}$ $\mathrm{NaCl}, 2 \mathrm{mM}$ EGTA, $50 \mathrm{mM}$ Tris- $\mathrm{HCl}, \mathrm{pH} 7.5$, protease inhibitors) containing $1 \%(\mathrm{w} / \mathrm{v})$ Triton X-100. After 30 min on ice, each sample was adjusted to $1.2 \mathrm{M}$ sucrose, placed in a centrifuge tube and overlaid with a linear gradient ranging from 30 to $5 \%$ sucrose (all prepared in buffer A). The gradients were centrifuged at $190000 \times \mathrm{g}$ for 19 hs using a rotor SW $41 \mathrm{Ti}$ (Beckman Instruments). Fifteen fractions ( $0.8 \mathrm{ml}$ each), and the pellets resuspended in $0.8 \mathrm{ml}$ of buffer A were collected and analysed by means of SDS-PAGE and western blotting. The sucrose concentration in each fraction was determined by refractometry.

\section{Western blot analysis}

Equal amount of sucrose gradient samples was separated by electrophoresis on 10\%-12\% SDS-PAGE and transferred to nitrocellulose membranes Hybond-C extra (Amersham Biosciences, Cologno Monzese, Italy). The filters were pre-wetted in 5\% non-fat milk in TBS-T $(10 \mathrm{mM}$ Tris pH 8, $150 \mathrm{mM} \mathrm{NaCl}, 0.1 \%$ Tween 20), hybridized overnight with rabbit anti-P2 $\mathrm{Y}_{1}(1: 400)$ and with mouse anti-Flotillin-2 (1:1000), followed by horseradish peroxidase-coupled secondary antibody, and analysed by ECL chemiluminescence (Amersham Biosciences), using Kodak Image Station (KDS IS440CF).

\section{Anti-P2Y, specificity}

The polyclonal $\mathrm{P} 2 \mathrm{Y}_{1}$ antiserum used in this study was raised against a $P 2 Y_{1}$ receptor highly purified peptide (identity confirmed by mass spectroghraphy and aminoacid analysis), corresponding to a specific epitope not present in any other known protein: residues 242-258 of rat and human $\mathrm{P}_{2} \mathrm{Y}_{1}$ ( $3^{\text {rd }}$ intracellular loop). The specificity of the $\mathrm{P}_{2} \mathrm{Y}_{1}$ receptor signal was assessed by incubating western blots either in the absence of the primary antiserum, or in the presence of the primary antiserum together with the neutralizing $\mathrm{P} 2 \mathrm{Y}_{1}$ immunogenic peptide ( $\mu \mathrm{g}$ protein ratio $1: 1$ between peptide and antiserum). Furthermore, the $\mathrm{P} 2 \mathrm{Y}_{1}$ receptor polyclonal antiserum was proved to efficiently immunoprecipitate the recombinant Myc$\mathrm{P}_{2} \mathrm{Y}_{1}$ human receptor transiently transfected in SH-SY5Y cells.

\section{Abbreviations}

DCX, doublecortin; D $\beta \mathrm{H}$, dopamine $\beta$-hydroxylase; egl, external granule layer; GFAP, glial fibrillary acidic protein; gl, granule layer; igl, internal granule layer; $\mathrm{ml}$, molecular layer; NeuN, neuronal nuclei; NFL, neurofilament-L protein; pc, Purkinje cells; pl, Purkinje layer; postnatal day 7 , P7; postnatal day 21, P21; TH, tyrosine hydroxylase.

\section{Authors' contributions}

SA carried out the immunohistological analysis, participated in the western blot examination and in the design 
of the study. FV purified lipid rafts from total cerebellar tissue and participated in the western blot examination. AM and GS performed electron microscopy analysis. CV conceived and coordinated the study, and participated in its design. All authors read and approved the final manuscript.

\section{Acknowledgements}

The research presented was supported by Cofinanziamento MIUR "Purinoceptors and Neuroprotection", and grant from Ministero della Salute RF05.105V. We thank Dr. Nadia D'Ambrosi for experiments with recombinant Myc-P2Y, human receptor transiently transfected in SH-SY5Y cells, and Dr. Patrizia Rosa and Elena Saba for the preparation of synaptosomal lipid rafts-enriched fractions.

\section{References}

I. Illes P, Ribeiro JA: Neuronal P2 receptors of the central nervous system. Curr Top Med Chem 2004, 4:83I-838.

2. Burnstock G: Pathophysiology and therapeutic potential of purinergic signaling. Pharmacol Rev 2006, 58:58-86.

3. Burnstock G: Historical review: ATP as a neurotransmitter. Trends Pharmacol Sci 2006, 27:166-176.

4. Burnstock G, Knight GE: Cellular distribution and functions of P2 receptor subtypes in different systems. Int Rev Cytol 2004, 240:3I-304.

5. Volonté C, Amadio S, D'Ambrosi N, Colpi M, Burnstock G: P2 receptor web: complexity and fine-tuning. Pharmacol Ther I I 2(I):264-280

6. Köles L, Furst S, Illes P: Purine ionotropic (P2X) receptors. Curr Pharm Des in press.

7. Abbracchio MP, Burnstock G, Boeynaems JM, Barnard EA, Boyer JL, Kennedy C, Knight GE, Fumagalli M, Gachet C, Jacobson KA, Weisman GA: Update of the P2Y G protein-coupled nucleotide receptors: from molecular mechanisms and pathophysiology to therapy. Pharmacol Rev 2006, 58(3):28I-34I.

8. Ralevic $V$, Burnstock $G$ : Receptors for purines and pyrimidines. Pharmacol Rev 1998, 50:413-492.

9. Communi D, Gonzalez NS, Detheux M, Brezillon S, Lannoy V, Parmentier M, Boeynaems JM: Identification of a novel human ADP receptor coupled to G(i). | Biol Chem 200I, 276:4I479-4|485.

10. Abbracchio MP, Boeynaems JM, Barnard EA, Boyer JL, Kennedy C, Miras-Portugal MT, King BF, Gachet C, Jacobson KA, Weisman GA, Burnstock G: Characterization of the UDP-glucose receptor (re-named here the P2YI4 receptor) adds diversity to the P2Y receptor family. Trends Pharmacol Sci 2003, 24:52-55.

II. Moore D, Chambers J, Waldvogel H, Faull R, Emson P: Regional and cellular distribution of the $\mathbf{P} 2 Y(I)$ purinergic receptor in the human brain: striking neuronal localisation. I Comp Neurol 2000, 42 I:374-384.

12. Moran-Jimenez MJ, Matute C: Immunohistochemical localization of the P2Y(I) purinergic receptor in neurons and glial cells of the central nervous system. Brain Res Mol Brain Res 2000, 78:50-58.

13. Moore D, Iritani S, Chambers J, Emson P: Immunohistochemical localization of the P2YI purinergic receptor in Alzheimer's disease. Neuroreport 2000, I I:3799-3803.

14. Franke H, Illes P: Involvement of $\mathbf{P 2}$ receptors in the growth and survival of neurons in the CNS. Pharmacol Therapeut 2006, 109:297-324.

15. James G, Butt AM: P2Y and P2X purinoceptor mediated $\mathbf{C a 2 +}$ signalling in glial cell pathology in the central nervous system. Eur J Pharmacol 2002, 447:247-260.

16. Fields RD, Burnstock G: Purinergic signalling in neuron-glia interactions. Nat Rev Neurosci 2006, 7:423-436.

17. Amadio S, Tramini G, Martorana A, Viscomi MT, Sancesario G, Bernardi G, Volonté C: Oligodendrocytes express $\mathbf{P 2 Y}_{12}$ metabotropic receptor in adult rat brain. Neuroscience 2006 |4|: | |7|-| | 80

18. Agresti C, Meomartini ME, Amadio S, Ambrosini E, Serafini B, Franchini L, Volonté C, Aloisi F, Visentin S: Metabotropic P2 receptor activation regulates oligodendrocyte progenitor migration and development. Glia 2005, 50:132-144.

19. Scemes E, Duval N, Meda P: Reduced expression of P2YI receptors in connexin43-null mice alters calcium signaling and migration of neural progenitor cells. J Neurosci 2003, 23: I | 4444-I| 452 .

20. Nelson TE, King JS, Bishop GA: Distribution of tyrosine hydroxylase-immunoreactive afferents to the cerebellum differs between species. J Comp Neurol 1997, 379:443-454.

21. Bickel PE, Scherer PE, Schnitzer JE, Oh P, Lisanti MP, Lodish HF: Flotillin and epidermal surface antigen define a new family of caveolae-associated integral membrane proteins. J Biol Chem 1997, 272: I3793-13802.

22. Wang L, Karlsson L, Moses S, Hultgardh-Nilsson A, Andersson M, Borna C, Gudbjartsson T, Jern S, Erlinge D: P2 receptor expression profiles in human vascular smooth muscle and endothelial cells. J Cardiovasc Pharmacol 2002, 40:84I-853.

23. Altman J, Bayer SA: An overview of the postnatal development of the rat cerebellum. In Development of the cerebellar system: in relation to its evolution, structure, and functions Boca Raton, FL: CRC; 1997:324-333.

24. Rakic P: Neuron-glia relationship during granule cell migration in developing cerebellar cortex. A Golgi and electronmicroscopic study in Macacus Rhesus. J Comp Neurol 197I, I 41:283-3|2.

25. Gleeson JG, Lin PT, Flanagan LA, Walsh CA: Doublecortin is a microtubule associated protein and is expressed widely by migrating neurons. Neuron 1999, 23:257-27I.

26. Altman J: Postnatal development of the cerebellar cortex in the rat. III. Maturation of the components of the granular layer. J Comp Neurol 1972, 145:465-5 I4.

27. Liesi P, Akinshola E, Matsuba K, Lange K, Morest K: Cellular migration in the postnatal rat cerebellar cortex: confocal-infrared microscopy and the rapid Golgi method. J Neurosci Res 2003 , 72:290-302.

28. Verney C, Grzanna R, Farkas E: Distribution of dopamine-betahydroxylase-like immunoreactive fibers in the rat cerebellar cortex during ontogeny. Dev Neurosci 1982, 5:369-374.

29. Takada M, Sugimoto T, Hattori T: Tyrosine hydroxylase immunoreactivity in cerebellar Purkinje cells of the rat. Neurosci Lett 1993, 150(1):61-64.

30. Beaudet $A$, Descarries $L$ : The monoamine innervation of rat cerebral cortex: synaptic and non-synaptic axon terminals. Neuroscience 1978, 3:85I-860.

31. Li B, Chen N, Luo T, Otsu Y, Murphy TH, Raymond LA: Differential regulation of synaptic and extra-synaptic NMDA receptors. Nat Neurosci 2002, 5:833-834.

32. Fuxe K, Agnati LF: Two principal modes of electrochemical communication in the brain: volume versus wiring transmission. In Volume transmission in the brain. Novel mechanisms for neuronal transmission Edited by: Fuxe K, Agnati LF. New York: Raven Press; 1991:1-9.

33. Hering $H$, Lin CC, Sheng $M$ : Lipid rafts in the maintenance of synapses, dendritic spines, and surface AMPA receptor stability. J Neurosci 2003, 23:3262-3271.

34. Yao ST, Lawrence AJ: Purinergic modulation of cardiovascular function in the rat locus coeruleus. Br J Pharmacol 2005, I 45:342-352

35. Mortani Barbosa EJ, Ferreira ZS, Markus RP: Purinergic and noradrenergic cotransmission in the rat pineal gland. Eur $J$ Pharmacol 2000, 401:59-62.

36. Vonend O, Stegbauer J, Sojka J, Habbel S, Quack I, Robaye B, Boeynaems JM, Rump LC: Noradrenaline and extracellular nucleotide cotransmission involves activation of vasoconstrictive P2X(I,3)- and P2Y6-like receptors in mouse perfused kidney. BrJ Pharmacol 2005, 145:66-74.

37. Thomas SA, Matsumoto AM, Palmiter RD. Noradrenaline is essential for mouse fetal development. Nature 1995, 374:643-646.

38. Cartford MC, Gould T, Bickford PC: A central role for norepinephrine in the modulation of cerebellar learning tasks. Behav Cogn Neurosci Rev 2004, 3: 131-138.

39. Yamada K, Watanabe M: Cytodifferentiation of Bergmann glia and its relationship with Purkinje cells. Anat Sci Int 2002 77:94-108. 
40. Oomman S, Strahlendorf H, Finckbone V, Strahlendorf J: Non-lethal active caspase-3 expression in Bergmann glia of postnatal rat cerebellum. Brain Res Dev Brain Res 2005, I 60: I30- | 45.

4I. Tohgo A, Eiraku M, Miyazaki T, Miura E, Kawaguchi SY, Nishi M, Watanabe M, Hirano T, Kengaku M, Takeshima H: Impaired cerebellar functions in mutant mice lacking DNER. Mol Cell Neurosci 2006, 3 I:326-333.

42. Solecki DJ, Model L, Gaetz J, Kapoor TM, Hatten ME: Par6alpha signaling controls glial-guided neuronal migration. Nat Neurosci 2004, 7: I195-1203.

43. Weller M, Krautler N, Mantei N, Suter U, Taylor V: Jagged I ablation results in cerebellar granule cell migration defects and depletion of Bergmann glia. Dev Neurosci 2006, 28:70-80.

44. Jones FE, Golding JP, Gassmann M: ErbB4 signaling during breast and neural development: novel genetic models reveal unique ErbB4 activities. Cell Cycle 2003, 2:555-559.

45. Rio C, Rieff HI, Qi P, Khurana TS, Corfas G: Neuregulin and erbB receptors play a critical role in neuronal migration. Neuron 1997, I 9:39-50.

46. Hatten ME: Central nervous system neuronal migration. Annu Rev Neurosci 1999, 22:51 I-539.

47. Edmondson JC, Liem RK, Kuster JE, Hatten ME: Astrotactin: a novel neuronal cell surface antigen that mediates neuronastroglial interactions in cerebellar microcultures. J Cell Biol 1988, I06:505-517.

48. Kirischuk S, Moller T, Voitenko N, Kettenmann H, Verkhratsky A: ATP-induced cytoplasmic calcium mobilization in Bergmann glial cells. J Neurosci 1995, | 5:786 |-787|

49. Merlo $D$, Volonté $C$ : Binding and functions of extracellular ATP in cultured cerebellar granule neurons. Biochem Bioph Res Co 1996, 225:907-9|4.

50. Daniel JL, Dangelmaier C, Jin J, Ashby B, Smith JB, Kunapuli SP. Molecular basis for ADP-induced platelet activation. I. Evidence for three distinct ADP receptors on human platelets. J Biol Chem 1998, 273:2024-2029.

5I. Jantzen HM, Gousset L, Bhaskar V, Vincent D, Tai A, Reynolds EE Conley PB: Evidence for two distinct G-protein-coupled ADP receptors mediating platelet activation. Thromb Haemost 1999, 8I:III-II7.

52. Gachet C: ADP receptors of platelets and their inhibition. Thromb Haemost 2001, 86:222-232.

53. Peters A, Palay SL, Webster HD: The fine structure of the nervous system Oxford University Press; 1991.

54. Iwabuchi K, Yamamura S, Prinetti A, Handa K, Hakomori S: GM3enriched microdomain involved in cell adhesion and signal transduction through carbohydrate-carbohydrate interaction in mouse melanoma BI6 cells. I Biol Chem 1998, 273:9130-9138

55. Vacca F, Amadio S, Sancesario G, Bernardi G, Volonté C: P2X3 receptor localizes into lipid rafts in neuronal cells. J Neurosci Res 2004, 76:653-661.

56. Huttner WB, Schiebler W, Greengard P, De Camilli P: Synapsin I (protein I), a nerve terminal-specific phosphoprotein. III. Its association with synaptic vesicles studied in a highly purified synaptic vesicle preparation. J Cell Biol I983, 96:1374-I388.
Publish with Biomed Central and every scientist can read your work free of charge

"BioMed Central will be the most significant development for disseminating the results of biomedical research in our lifetime. "

Sir Paul Nurse, Cancer Research UK

Your research papers will be:

- available free of charge to the entire biomedical community

- peer reviewed and published immediately upon acceptance

- cited in PubMed and archived on PubMed Central

- yours - you keep the copyright
BioMedcentral 